\title{
Path Analysis in Rice Yield and Yield Attributing Characters by Structural Equation Model
}

\author{
Neelam Chouksey $^{1 *}$, G. C. Mishra ${ }^{2}$ and Rajesh Chouksey ${ }^{3}$ \\ ${ }^{1}$ Agricultural Statistics, RMD college of Agriculture \& Res. Sta. Ambikapur (C.G.), India \\ ${ }^{2}$ Agricultural Statistics, Institute of Agricultural Science, \\ Banaras Hindu University, Varanasi (U.P.), ${ }^{3}$ Soil science, Krishi Vigyan Kendra, \\ Surguja, India \\ *Corresponding author
}

\section{A B S T R A C T}

\begin{tabular}{l} 
K e y w o r d s \\
$\begin{array}{l}\text { Structural equation } \\
\text { model, Path } \\
\text { analysis, } \\
\text { Multidirectional } \\
\text { relationship }\end{array}$ \\
\hline Article Info \\
\hline $\begin{array}{l}\text { Accepted: } \\
\text { 26 April } 2020 \\
\text { Available Online: } \\
\text { 10 May } 2020\end{array}$ \\
\hline
\end{tabular}

A Structural Equation Model has been used to investigate the multidirectional causal relationship among agricultural characteristics such as nitrogen content in the soil $(\mathrm{kg} / \mathrm{ha})$, Rice yield $(\mathrm{kg} / \mathrm{ha})$, nitrogen uptake by rice $(\mathrm{kg} / \mathrm{ha})$ and organic carbon $(\mathrm{kg} / \mathrm{ha})$. There using time series data of experimental project on Raipur district of Chhattisgarh from 1993 to 2017, this paper investigates the separate but simultaneous impact of different character on yield. After investigation through the structural equation model, a highly significant and positive effect found for nitrogen content on nitrogen uptake $\&$ yield. Nitrogen uptake positively affects on yield, but organic carbon negatively and lowest affects on nitrogen uptake \& yield. Our paper provides a technique for a better understanding of multidirectional relationship among several key characteristics. By the technique inclusion of many relevant variables are possible and can be weeding out irrelevant characters. So that, by path analysis researcher can search specific relations among the variables.

\section{Introduction}

Path technique is a type of multiple linear regression analysis and it is used for analyzing cause and effect relationship of variables. Investigators prepare regressions model to analyze influences on dependent variables though path analysis. "A regression is conducted for each dependent variable and effects are calculated across regressions for cumulative effects. But in path analysis consists of a family of models that depicts the influence of a set of variables on one another" (Spaeth, 1975). "Path analysis is closely related to multiple regressions. In other word, it is an extension of the regression model, which researchers use to test the fit of a correlation matrix with a causal model that 
they test" (Garson, 2004). The aim of path analysis is to provide significance effects and estimates of the magnitude by causal connections among sets of variables through the use of path diagrams. A path diagram is a diagrammatic presentation of connected variables. There are independent $(\mathrm{X})$ variables and dependent (Y) directly or indirectly connected to each other. In path diagram single headed arrow shows that direct connection between variable and double headed arrow indicate correlation (two side association) between variables.

In path analysis, path coefficients are indicated direct connection of one variable to another variable. Two types of path coefficients are used in path model, one is Standardized coefficients and other is unstandardized. Standardized coefficients are obtained from standardization of the path model and they are estimated by correlation coefficients. So that it is mostly used in path analysis rather than unstandardized coefficients. Same assumption is required in path analysis like regression analysis. There are also important requirement is a adequate size of sample to accurate estimation and test of significance. Klein (1998) suggested a ratio is 20 sample per variable measured in the model. In general, the efficiency and accuracy of a path analysis is increased with increasing sample size and number of variables. Lea (1997) recommended the testing of significance of path model with goodness of fit test by using a structural equation modeling program.

Path analysis can be better used to analyze models that are more complex (and realistic) than multiple regression. In the study we are using path analysis to identify the casual relationship among some agricultural characters. There are many researcher, they used path analysis in agricultural and biometrical characters.
Yield is affected by more than one characters therefore, it is impotent to find out that which character contribute more to yield. According to correlation coefficient estimates are not enough in case where independent characters associated to each other or they are indirectly associated with dependent variables. So, studies of correlation with path analysis have more efficient and effective technique for yield attributing characters (Mahajan et al., 2011). By the path analysis we can partition correlation effects in to direct and indirect effect of the causal components on the complex component. In different yield component traits, cause of variability may be helpful for improving yield (Mehandi et al., 2013). Path coefficient analysis is an efficient statistical technique, which provides means to identifying relationship between different yield components and indicates weather the influence is directly or indirectly affects in the yield (Ahmad et al., 2003).

\section{Materials and Methods}

The theoretical framework for the study has been drawn from four variables: Rice yield, nitrogen uptake, nitrogen content and organic carbon. For the purpose yearly data of nitrogen content in the soil $(\mathrm{kg} / \mathrm{ha})$, Rice yield ( $\mathrm{kg} / \mathrm{ha})$, nitrogen uptake by rice $(\mathrm{kg} / \mathrm{ha})$ and organic carbon $(\mathrm{kg} / \mathrm{ha})$ from year 1993 to 2017 for Raipur district of Chhattisgarh have used. Path diagram as shown in Fig. 1 has been prepared to depict the relationship between yield, nitrogen content, nitrogen uptake and organic carbon. Validity of path model is confirmed because there is a high correlation between (a) nitrogen content \& nitrogen uptake (b) nitrogen uptake \& yield, and (c) yield \& nitrogen content and low or negative correlation is found between (a) organic carbon \& yield (b) organic carbon \& nitrogen uptake. Both direct and indirect (mediated) effects have been examined by the help of structural equation model. 
The structure of the path model is shown in Fig. 1. There, direct and indirect effect of yield attributing characters have been analysed by the suggestion of Wright (1921). Path model is basically generated by transformation on multiple regression models. Suppose in a set of $n+1$ random variables, we wish to estimate $y$ by a linear combination of the $\mathrm{x}_{1}, \mathrm{x}_{2}, \ldots \ldots, \mathrm{x}_{\mathrm{n}}$. Then multiple linear regression model is:

$y=\beta_{0}+\beta_{1} x_{1}+\ldots \ldots \ldots+\beta_{n} x_{n}+e$

The residual e has zero expectation and is uncorrelated pairwise with each of $\mathrm{x}_{1}, \mathrm{x}_{2}, \ldots \ldots$, $\mathrm{x}_{\mathrm{n}}$. Equation (3.39) can be simply be rewritten as:

$\left[y-\bar{y}=\beta_{1}\left(x_{1}-\bar{x}_{1}\right)+\beta_{2}\left(x_{2}-\bar{x}_{2}\right)+\ldots \ldots \ldots+\beta_{n}\left(x_{n}-\bar{x}_{n}\right)+e\right]$

If we divide the equation (2) by $\sigma_{\mathrm{y}}$ throughout we have in fact standardized dependent variable (y) and make the similar transformation on $\mathrm{x}_{1}, \mathrm{x}_{2}, \ldots \mathrm{x}_{\mathrm{n}}$. Equation can be rewritten as:

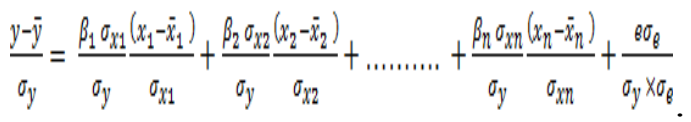

Than Path Equation can be written as:

$\mathrm{Y}=\mathrm{p}_{1} \mathrm{X}_{1}+\mathrm{p}_{2} \mathrm{X}_{2} \ldots \mathrm{p}_{\mathrm{n}} \mathrm{X}_{\mathrm{n}}+\mathrm{p}_{\mathrm{e}} \mathrm{E}$

Where,

$\mathrm{Y}=(y-\bar{y}) / \sigma_{y}, \mathrm{X}=(x-\bar{x}) / \sigma_{x}$,

$\mathrm{p}_{\mathrm{e}}=\beta_{\mathrm{n}} \sigma_{\mathrm{x}} / \sigma_{\mathrm{y}}, \mathrm{E}=\mathrm{e} / \sigma_{\mathrm{e}}$

The $p_{i}^{\prime} s(i=1, \ldots, n)$ are standardized partial regression coefficients (path coefficients) and it is also known as direct effect of independent variable on dependent variable. The indirect effect of $y$ on $x_{1}$ via $x_{2}$ is $p_{2} r_{12}$ and via $x_{n}$ is $p_{n} r_{1 n}$. Where $r_{12} \ldots r_{1 n}$ are the correlation coefficient between $\mathrm{x}_{1}$ and $\mathrm{x}_{2}$ ,$\ldots . . \mathrm{x}_{1}$ and $\mathrm{x}_{\mathrm{n}}$. Their path analysis has been analyzed through AMOS SPSS 20 software.

\section{Results and Discussion}

Based on the conceptual framework, the relationships of each of the variables have been examined using the network or standardized beta approach. The structural model is focused on the relationship between dependent and independent variables. The relationships have measured by path coefficient $(\beta)$.

"The strength of the relations is based upon the beta value according to the following categories: $\beta<0.2$ is a weak effect, $\beta$ between 0.2 and 0.5 is a moderate effect, $\beta>.5$ is a strong effect (Chin et al., 2003, Cohen, 1977)".

After analyzing of variables by path analysis, It can be seen in Table 1 that the inclusion of organic carbon and nitrogen content as an independent variable in regression perform better and significance influence on nitrogen uptake (0.402) in comparison to nitrogen content and nitrogen uptake on yield (0.334).

According to the beta values (path coefficients), organic carbon had a negligible effect on nitrogen uptake $(\beta=-0.026)$. Nitrogen uptake \& nitrogen content performed moderate effect on yield $(\beta$ $=0.299) \&(\beta=0.340)$ respectively. Whereas, nitrogen content has been strong effect on nitrogen uptake $(\beta=0.425)$.

There is significant interaction for path coefficient between the nitrogen uptake as a dependent variable and nitrogen content as independent variables $(\mathrm{p}=0.001)$ and nitrogen content on rice yield $(\mathrm{p}=.014)$ has also statistically significant interaction.

Fig. 2 shows that the structure of model, which depicts the relationship between rice yields, nitrogen content in soil, nitrogen uptake by rice and organic carbon. 
Table.1 Path coefficients based on the path model

\begin{tabular}{|l|l|l|c|c|c|c|}
\hline $\begin{array}{l}\text { Outcome } \\
\text { variable }\end{array}$ & $\begin{array}{l}\text { R } \\
\text { squared }\end{array}$ & $\begin{array}{l}\text { Predictor } \\
\text { variable }\end{array}$ & S.E. & $\begin{array}{c}\text { P } \\
\text { value }\end{array}$ & $\begin{array}{c}\text { Standardized } \\
\text { path Estimate( } \boldsymbol{\beta})\end{array}$ & Strength \\
\hline Nitrogen & 0.402 & nitrogen content & 0.15 & 0.001 & 0.631 & Strong \\
\hline uptake & & organic carbon & 19.22 & 0.868 & -0.026 & Weak \\
\hline Rice yield & 0.334 & nitrogen uptake & 9.21 & 0.165 & 0.299 & Moderate \\
\cline { 3 - 7 } & & nitrogen content & 8.99 & 0.014 & 0.340 & Moderate \\
\hline
\end{tabular}

Table.2 Direct and indirect effect

\begin{tabular}{|l|l|c|c|c|}
\hline $\begin{array}{l}\text { Outcome } \\
\text { variable }\end{array}$ & Predictor variable & $\begin{array}{c}\text { Standardized } \\
\text { direct effect }\end{array}$ & $\begin{array}{c}\text { Standardized } \\
\text { indirect effect }\end{array}$ & $\begin{array}{c}\text { Total } \\
\text { effect }\end{array}$ \\
\hline $\begin{array}{l}\text { nitrogen } \\
\text { uptake }\end{array}$ & organic carbon & -0.026 & 0.000 & -0.026 \\
\hline Yield & nitrogen content & 0.631 & 0.000 & 0.631 \\
\hline organic carbon & 0.000 & -0.008 & -0.008 \\
\hline nitrogen content & 0.340 & 0.189 & 0.529 \\
\hline nitrogen uptake & 0.299 & 0.000 & 0.299 \\
\hline
\end{tabular}

Fig.1 Structure of the path model

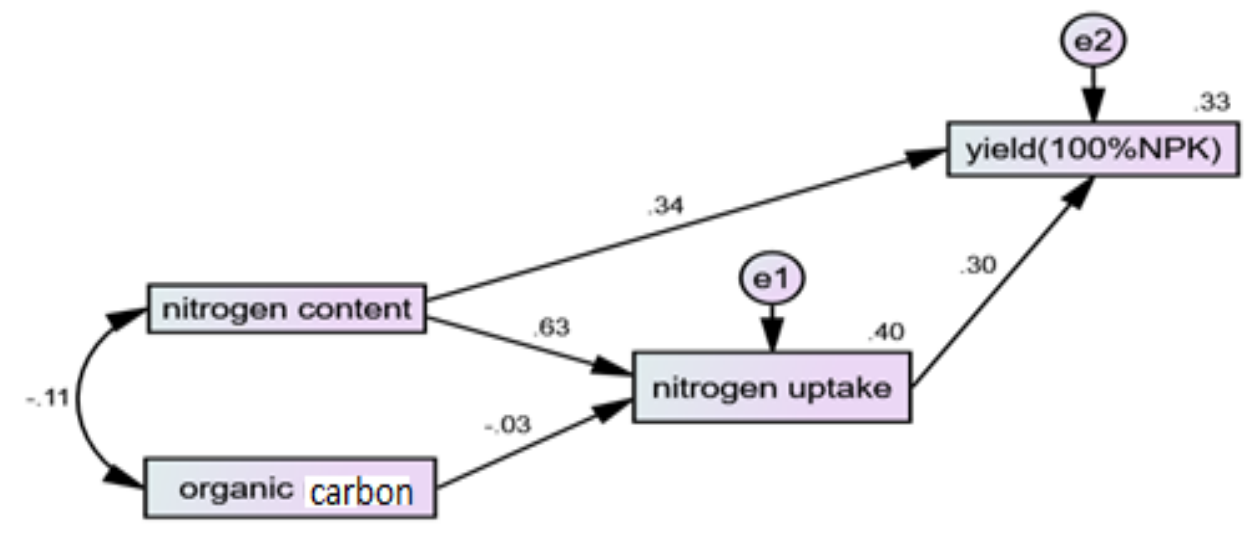

Fig.2 Structure of the path model

After analyzing the final network model the strongest network path (0.631) was shown in table 2, the variable which exhibited nitrogen content on nitrogen uptake and 
medium associated path (0.340) was nitrogen content on rice yield while, weakly associated path (0.00) was organic carbon on rice yield and organic carbon on nitrogen uptake (0.026). Therefore, nitrogen content in soil is the much more important as comparison to other selecting variables during consideration of direct relationships.

While considering the indirect effects listed in Table 2, nitrogen content in soil on rice yield (0.189) was the highest indirect strength. Thus, while nitrogen content in soil has a strong direct effect on nitrogen uptake, but it is also had a greatest magnitude of indirect strengths for rice yield. Expressing it in the another way, nitrogen content in soil exhibiting a strong direct link as well as exhibited a indirect influence through the other predictor variables.

Structural Equation Model is a powerful statistical technique for Path analysis that allows for more complex models than multiple regressions with its single dependent variable. In the study, we suggested how to choose strongly related characters through path analysis among yield, nitrogen content, organic carbon and nitrogen uptake. After that, direct and indirect influence was identified.

Direct effect is the direct contribution of explanatory variable to dependent variable. Cause of indirect effect may be due to other predictor variables. There also concluded that, by this technique, inclusion of many relevant variables is possible and can be weeding out irrelevant characters. So that researcher can search specific relations among the variables.

\section{References}

Ahmad, H.M., Khan, B.M., Khan, S., Sadiq Kissana, N. and Sawan Laghari. (2003). Path coefficient analysis in bread wheat. Asian J. Plant Sci., 2: 491-194.
Chin, W. W., Marcolin, B. L., and Newsted, P. R. (2003). A partial least squares latent variable modelling approach for measuring interaction effects: Results from a Monte Carlo simulation study and an electronic-mail emotion/adoption study. Information Systems Research, 1(2): 189-217.

Cohen, J. (1977). Statistical power analysis for the behavioral sciences (revised edition.). New York, NY: Academic Press.

Garson, G. D. (2004). Multivariate analysis for applied social science. Retrieved March 14, 2004, from http://www2.chass.ncsu.edu/garson/ pa765/path.htm

Klein, R. B. (1998). Principles and practice of structural equation modeling. New York: Guilford Press.

Lea, S. (1997). Path analysis. University of Exeter. Retrieved July 14, 2004, from http://www.ex.ac.uk/ SEGLea/multvar2 /oldwelcome. html

Mahajan, R.C., Wadikar, P.B., Pole, S.P. and Dhuppe, M.V. (2011). Variability, correlation and path analysis studies in sorghum. Research Journal of Agriculture Science, 2: 101-103.

Mehandi, S., Singh, C. M. and Kushwaha, V. K. (2013). Estimates of genetic variability and heritability for Yield and yield component traits in mungbean. The Bioscan., 8: 1481-1484.

Pedhazur, E. J. (1997). Multiple regression in behavioral research: Explanation and prediction. New York: Holt, Rinehart and Winston.

Spaeth, J. L. (1975). Path analysis: Introductory multivariate analysis. In D. J. Amick \& H. J. Walberg (Eds.), Introductory multivariate analysis:For educational, psychological, and social research (pp. 53-89). Berkeley,CA: McCutchan.

Wright, S. (1921). Correlation and Causation. J. Agric. Sci., 20: 557-587. 


\section{How to cite this article:}

Neelam Chouksey, G. C. Mishra and Rajesh Chouksey. 2020. Path Analysis in Rice Yield and Yield Attributing Characters by Structural Equation Model. Int.J.Curr.Microbiol.App.Sci. 9(05): 3098-3103. doi: https://doi.org/10.20546/ijcmas.2020.905.367 